\title{
OPEN In vitro expansion of fetal liver hematopoietic stem cells
}

\author{
Rashmi Bhardwaj ${ }^{1}$, Lalit Kumar ${ }^{1}$, Deepika Chhabra ${ }^{2 \bowtie}$, N. K. Mehra ${ }^{1}$, Atul sharma ${ }^{1}$, \\ Sujata Mohanty ${ }^{1} \&$ Vinod Kochupillai $^{2}$
}

Fetal liver hematopoietic stem and progenitor cells (HSPCs) have been considered appropriate for the management of aplastic anemia owing to their proliferative potential. Bone marrow recovery was possible in some cases; the engraftment potential of these cells, however was unsatisfactory, possibly due to the availability of a smaller number of these cells from a single fetus. The present study explores how we can expand fetal liver hematopoietic stem cells under in vitro conditions. We isolated mononuclear cells from fetal liver and hematopoietic stem cells were identified and analyzed by cell surface marker CD34. CD34 ${ }^{+}$fetal liver HSPCs cells were separated by magnetic cell sorting positive selection method. HSPCs $\left(\mathrm{CD}_{3} 4^{+}\right)$were cultured by using 5 cytokines, stem cell factor (SCF), granulocyte macrophages-colony stimulating factor (GM-CSF), interleukin-6 (IL-6), Fmsrelated tyrosine kinase 3 (FLT-3) and erythropoietin (EPO), in 4 different combinations along with supplements, in serum-free culture media for 21 days. Cell viability continued to be greater than $90 \%$ throughout 21 days of culture. The cells expanded best in a combination of media, supplements and 5 cytokines, namely SCF, FLT-3, IL6, EPO and GM-CSF to yield a large number of total (CD34 ${ }^{+}$\& CD34) cells. Even though the total number of nucleated cells increased in culture significantly, levels of CD34 antigen expression declined steadily over this period.

Hematopoiesis appears in the fetal liver (FL) at approximately 5 weeks of gestation and remains the primary site of hematopoiesis until mid-gestation ${ }^{1}$. The HSPCs rapidly proliferate in the liver; undergo maturation and differentiation leading to erythropoiesis, myelopoiesis, B and T lymphopoiesis, and production of megakaryocytes ${ }^{2}$. Thereafter, the bone marrow replaces the fetal liver as the primary site of hematopoiesis ${ }^{3}$. HSPCs have been used to treat a number of nonmalignant conditions such as Aplastic Anemia (AA), Severe Combined Immunodeficiency Disease (SCID), Congenital Metabolic Disorders, and also malignant conditions such as Acute Myeloid Leukemia (AML), Acute Lymphoblastic Leukemia (ALL), Myelodysplastic Syndrome (MDS), Chronic Myeloid Leukemia (CML), and Multiple Myeloma (MM). Fetal liver cells have the advantage of better growth and differentiation because of their higher telomere content ${ }^{4}$. Also, the proportion of HSPCs (marked by surface antigen CD 34) in the fetal liver are greater than those found in cord blood and bone marrow; and are more or less equal to those found in mobilized peripheral blood ${ }^{5}$. Fetal liver hematopoietic stem and progenitor cells (FL-HSPCs) have been found to exhibit greater proliferative potential compared to the adult bone marrow and cord blood. Increased capacity in serial transfer, greater tritiated thymidine uptake index, evidenced this along with early appearance of the peak number of colonies in semi-solid assays and greater plating efficiency $y^{6,7,8,9}$. It was also found that these cells lack proper Human Leukocyte Antigen (HLA) expression ${ }^{10}$. With having all the abovementioned properties, fetal liver infusion has been utilized for the management of aplastic anemia ${ }^{11}$. A limited quantity of fetal liver cells obtained from a single abortus however, creates problems in carrying out different experiments in the laboratory. A regular supply of the FL-HSPCs, probably can be obtained from expanded cells. Expanded fetal liver CD34 ${ }^{+}$HSPCs produced under "in vitro" conditions may provide large homogenous population of cells from a single fetal liver source.

\section{Material and methods}

Ethical approval. The Human Ethics Committee (Institutional Review Board) of All India Institute of Medical Sciences, New Delhi, India approved the current study. The Patient Information sheet was shared and we obtained Informed consent from patients who underwent Medical Termination of Pregnancy (MTP). We confirm that we carried all methods as per the relevant guidelines and regulations.

\footnotetext{
${ }^{1}$ Institute Rotary Cancer Hospital (IRCH), All India Institute of Medical Sciences (AlIMS), New Delhi, India. ${ }^{2}$ Sri Sri Institute For Advanced Research (SSIAR), Ved Vignan Maha Vidhya Peeth (VVMVP), F003 Soudhamini Apartment, 21st Kanakpura Road, Art of Living International Center, Udaipura, Bengaluru 560082, India. ${ }^{\square}$ email: chhabra.deepika@gmail.com
} 


\begin{tabular}{|c|c|c|c|c|c|c|}
\hline $\begin{array}{l}\text { Cytokine used in } \\
\text { Combinations }\end{array}$ & Combination $1(\mathrm{M})$ & Combination $2(\mathrm{M}+\mathrm{S})$ & $\begin{array}{l}\text { Combination } 3 \\
(M+S+M 1)\end{array}$ & $\begin{array}{l}\text { Combination } 4 \\
(M+S+M 2)\end{array}$ & $\begin{array}{l}\text { Combination } 5 \\
(M+S+M 3)\end{array}$ & $\begin{array}{l}\text { Combination } 6 \\
(\mathrm{M}+\mathrm{S}+\mathrm{M} 4)\end{array}$ \\
\hline Media & Media & Media & Media & Media & Media & Media \\
\hline Supplements & & Supplements & Supplements & Supplements & Supplements & Supplements \\
\hline SCF & & & $100 \mathrm{ng} / \mathrm{ml}$ & $100 \mathrm{ng} / \mathrm{ml}$ & $100 \mathrm{ng} / \mathrm{ml}$ & $100 \mathrm{ng} / \mathrm{ml}$ \\
\hline FLT-3 & & & $100 \mathrm{ng} / \mathrm{ml}$ & $100 \mathrm{ng} / \mathrm{ml}$ & $100 \mathrm{ng} / \mathrm{ml}$ & $100 \mathrm{ng} / \mathrm{ml}$ \\
\hline IL-6 & & & & $20 \mathrm{ng} / \mathrm{ml}$ & $20 \mathrm{ng} / \mathrm{ml}$ & $20 \mathrm{ng} / \mathrm{ml}$ \\
\hline EPO & & & & & $2 \mathrm{U} / \mathrm{ml}$ & $2 \mathrm{U} / \mathrm{ml}$ \\
\hline GM-CSF & & & & & & $200 \mathrm{U} / \mathrm{ml}$ \\
\hline
\end{tabular}

Table 1. Combinations of Cytokines used for expansion of fetal liver hematopoietic stem and progenitor cells. $\mathrm{M}=$ Media, $\mathrm{S}=$ Supplements, M1 = SCF + Flt-3, M2 = SCF + Flt-3 + IL6, M3 = SCF + Flt-3 + IL6 + EPO, $\mathrm{M} 4=\mathrm{SCF}+\mathrm{Flt}-3+\mathrm{IL} 6+\mathrm{EPO}+\mathrm{GM}-\mathrm{CSF}$.

Preparation of cell suspension and cell viability. We obtained human fetuses with gestation periods ranging from 8 to 20 weeks with no known chromosomal abnormality following medical termination of pregnancy (MTP) with Prostaglandin E or Emcradyl injection from the Department of Obstetrics and Gynecology at AIIMS. Immediately after expulsion, we collected fetuses on ice and brought to the Laboratory. We dissected the fetuses under aseptic conditions to separate the liver. The liver was placed into Iscove's Modified Dulbecco Medium (IMDM) containing 10\% fetal bovine serum (FBS) and $10 \mathrm{IU} / \mathrm{ml}$ heparin. Further, the liver was mashed into small pieces and allowed to pass through sterile muslin cloth repeatedly to obtain single-cell suspension. $10 \mu \mathrm{l}$ of the fetal liver cell suspension was mixed with $10 \mu \mathrm{l}$ of Trypan blue dye and loaded onto a hemocytometer and the number of dye excluding cells (viable) were counted. Only those fetus samples which had $80 \%$ or more cell viability were taken up for further analysis.

Isolation of fetal liver mononuclear cells (MNC). Mononuclear cells from fetal liver nucleated cell suspension were separated using density gradient centrifugation for their subsequent use in culture studies. After 5 min of treatment with 1X Red Cell lysis buffer (Sigma) to remove mature erythrocytes and PBS washing, nucleated cells from fetal liver suspension were diluted with IMDM containing 10\% FBS in the ratio of 1:3 (fetal liver suspension: IMDM with FBS) and $30 \mathrm{ml}$ of this mix was gently layered on $10 \mathrm{ml}$ of Histopaque-1077 (Sigma Aldrich) in $50 \mathrm{ml}$ sterile centrifuge tubes. The mononuclear cells were isolated by centrifugation ( $30 \mathrm{~min}$, $1500 \mathrm{rpm}$, at room temperature) in a swinging-bucket rotor without brake. The white cell ring appearing at the interface of the medium and consisting of mononuclear cells (MNCs) was carefully withdrawn with a fine pasture pipette. MNCs so obtained were washed thrice in phosphate buffer saline (PBS) to remove any traces of Histopaque and cells were counted on a hemocytometer before labeling with magnetic bead or fluorochromeconjugated Antibodies.

Isolation of fetal liver hematopoietic stem and progenitor cells (CD34+ Cells) by MACS. The CD34 ${ }^{+}$HSPCs fraction was isolated immunomagnetically using $\mathrm{MS}^{+}$MiniMACS columns and the CD34 Direct Isolation Kit (Miltenyi Biotec, USA) as per manufatcurer's instructions. Aftre removal from MS coloumns and washing with PBS, the MACS sorted HSPCs were analysed for surface antigen CD34 through flow cytometer (BD FACS Calibur) using CD34PE antibody (BD Biosciences). Statistics were elaborated in 10,000 events/sample by WinMDI software. Purified CD34 + cells from MACS sorting were used for cell culture study.

Expansion of CD34+ FL-HSPCs under 'in vitro' conditions. We followed Stroma-free long-term culture technique to expand the FL- HSPCs. Freshly isolated $1 \mathrm{X} 10^{4} \mathrm{FL}$ CD $34^{+}$cells were cultured in a flat bottomed 24 well plates in $1 \mathrm{ml}$ of serum-deprived culture medium STEM PRO-34-SFM (Gibco, Thermo Fisher) supplemented with $100 \mu \mathrm{g} / \mathrm{ml}$ insulin (Sigma), $200 \mu \mathrm{g} / \mathrm{ml}$ transferrin (Sigma), $40 \mu \mathrm{g} / \mathrm{ml}$ low density lipoprotein (LDL) (Sigma), $2 \mathrm{mM}$ Glutamine (Gibco), $10^{-4} \mathrm{M}$ Mercaptoethanol (Sigma). Different cytokine combinations (Table 1) comprising SCF (100 ng/ml), FLT-3(100 ng/ml), IL-6(20 ng/ml), EPO (2U/ml) and GM-CSF (200U/ $\mathrm{ml}$ ), (Peprotech) were used to expand CD34 ${ }^{+}$HSPCs for a period of 21 days. Fetal liver CD34 $4^{+}$HSP cultures were grown at $37{ }^{\circ} \mathrm{C}$ in humidified $5 \% \mathrm{CO} 2$ incubator. Wells were demi- depopulated once a week. Harvested cells were counted and suitable aliquots were assayed every seven days for the presence of specific surface antigen CD34 by flow cytometry (BD FACS Calibur).

Colony forming unit assay. Colony Forming Unit (CFU assay) was performed from the in vitro expanded CD $34^{+}$HSPCs. $1 \times 10^{4}$ cells were taken from the expanded culture of Fetal liver CD34 ${ }^{+}$HSPCs at an interval of 7 days and mixed with methylcellulose semisolid medium (MethoCult H4434). Colony-forming unit-granulocyte macrophage (CFU-GM), Colony-forming unit-granulocyte magakaryocyte macrophage (CFU-GEMM), and Blast-forming unit- erythroid (BFU-E) were scored with an inverted microscope at day 14 of the culture.

Statistical analysis. All data about fetuses and culture characteristics were entered and analyzed using Microsoft excel and SPSS software. Statistical analysis was performed to determine the significance between two 


\begin{tabular}{|l|l|}
\hline Characteristics & Number \\
\hline Total Fetuses collected & 70 \\
\hline Sex Male: Female & $39(55.7 \%): 31(44.2 \%)$ \\
\hline Age (Gestation Period) & $13 \pm 2.91$ weeks \\
\hline Mean \pm SD & 12 weeks \\
\hline Median & $8-20$ weeks \\
\hline Range & $1.00 \pm 0.76 \mathrm{~h}$ \\
\hline Time between expulsion and processing of Fetus \\
\hline Mean & $0.25-3.5 \mathrm{~h}$ \\
\hline Range & $93.81 \pm 5.0 \%$ \\
\hline Non hepatocytic cell viability of liver cells & $85-100 \%$ \\
\hline Mean & $1.91 \pm 1.31 \times 10^{9}$ \\
\hline Range & $1.77 \times 10^{9} 0.02-$ \\
\hline Total viable Nucleated (Non Hepatocytic) Cells \\
\hline Mean \pm SD & $5.2 \times 10^{9}$ \\
\hline Median & $2.27 \pm 1.81 \times 10^{8}$ \\
\hline Range & $2.041 \times 10^{8}$ \\
\hline Total viable fetal liver mononuclear cells & $0.01-6.78 \times 10^{8}$ \\
\hline Mean \pm SD & \\
\hline Median & \\
\hline Range &
\end{tabular}

Table 2. Fetal liver characteristics at the time of collection.

culture populations with minimum of three replicates. Multivariate analysis ANOVA was done between groups to determine statistical significance $\left({ }^{\star \star} P \leq 0.01\right.$ and $\left.{ }^{\star * \star} P \leq 0.001\right)$.

\section{Results}

Cell number and viability range of human fetal liver. The age of the fetuses varied from $8-20$ weeks (Median $=12$ weeks). The median number of total fetal cells was $1.77 \times 10^{9}$ (Range; $0.02-5.2 \times 10^{9}$ ) with mean viability of $93.81 \pm 5 \%$. Total viable mononuclear cells obtained from fetal liver nucleated (Non Hepatocytic) cell suspension using density gradient centrifugation were $2.27 \pm 1.81 \mathrm{X} 10^{8}$ (Range; $0.01-6.78 \mathrm{X} 10^{8}$ ) (Table 2).

High CD34 expression on human fetal liver mononuclear cells. Fetal liver MNCs through flowcytometry showed that the total $\mathrm{CD} 34^{+}$HSPCs population ranged from $1.2 \%$ to $12.8 \%$ with a median value of $5.5 \%$. Supplementary Table 1 displays the percentage of CD34 ${ }^{+}$cells among FLMNCs according to gestational age. The peak values of CD34 ${ }^{+}$HSPCs were observed during 8-16 weeks of gestational age (Fig. 1a). From 8 to 10 th week, $\mathrm{CD} 34^{+}$percentage remained high $(8.50 \pm 2.4 \%$ to $8.70 \pm 1.8 \%)$; subsequently it started declining. We performed multivariate linear regression analysis on our results which shows that increase in gestational age of 1 week changes CD34 percentage by 0.8463 units. The overall regression model was significant and depicted $1 \%$ level of significance with a coefficient of determination $\left(\mathrm{R}^{2}\right)$ value at 0.9429 .

$\mathrm{CD}_{34}{ }^{+}$HSPCs purification. The total no. of CD34 ${ }^{+}$HSPCs separated by MACS positive selection method ranged from $5.20 \times 10^{5}-4.34 \times 10^{6}$ to (median $2.79 \times 10^{6}$ ) with a median recovery of $62.3 \%$ (range $31.8-75.3 \%$ ). The median purity of CD34+ HSPCs isolated from MiniMACS was 95\% (Range $89-98 \%$ ). In all samples, the percentage cell viability of $\mathrm{CD}_{3} 4^{+}$isolated HSPCs were greater than $95 \%$ as measured by Trypan blue dye exclusion methods. CD $34^{+}$cell fraction is nonadherent while CD34- cells adhere to the flask in culture media and this fraction of cells may contain fetal liver stromal cells ${ }^{12}$.

137 fold expansion of CD34+ fetal liver HSPCs. Estimated cell counts at 7 days intervals are shown in Fig. 2. Cell viability throughout 21 days of culture was greater than $90 \%$. Expansion of total cells was expressed as an increase over initial cell input. Total nucleated cells expanded up to $137.24 \pm 8.1$ fold $(M+S+M 4)$ by day $21(p<0.01)$. A multivariate approach was adapted by performing ANOVA to assess the difference in cell expansion between different culture conditions. Difference between average number of cells in $\mathrm{M}$ and $\mathrm{M}+\mathrm{S}+\mathrm{M} 4$ was highly significant $(-64.3555)$ as $\mathrm{p}$ value $(0.000)<0.01$ with $95 \%$ confidence level of interval. Highest average number of cells was found in combination $M+S+M 4$ followed by $M+S+M 3$ with mean difference significant at the 0.05 level. Analysis was also performed based on different timepoints and it was found that even at earlier timepoints of Day 7 and Day 14, difference between expanded average numbers was highly significant with $p$-value $(0.000)<0.01$ with $95 \%$ confidence level of interval.

Declining $\mathrm{CD}_{34}{ }^{+}$expression on expanded FL-HSPCs. Expanded cells observed from day 0 to day 21 , the percentage of $\mathrm{CD} 34^{+}$cells declined quickly after day seven and continued to decline steadily over the 


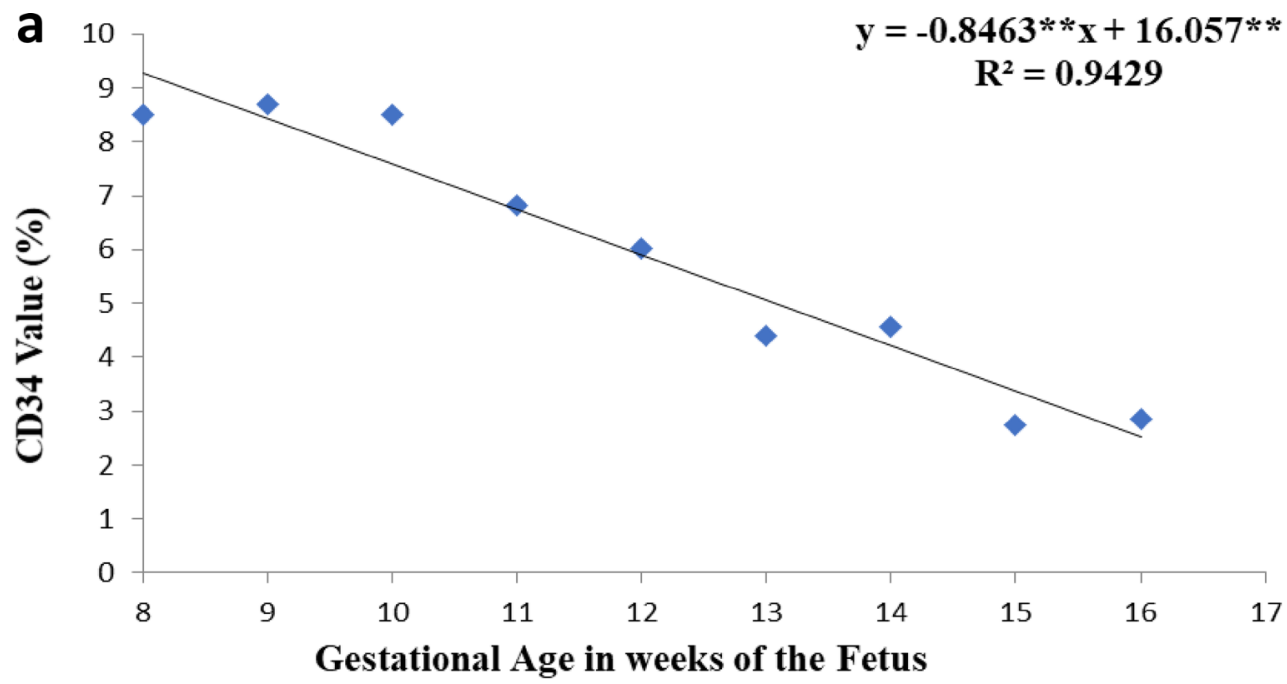

${ }^{* *}$ denotes significance at $1 \%$ level
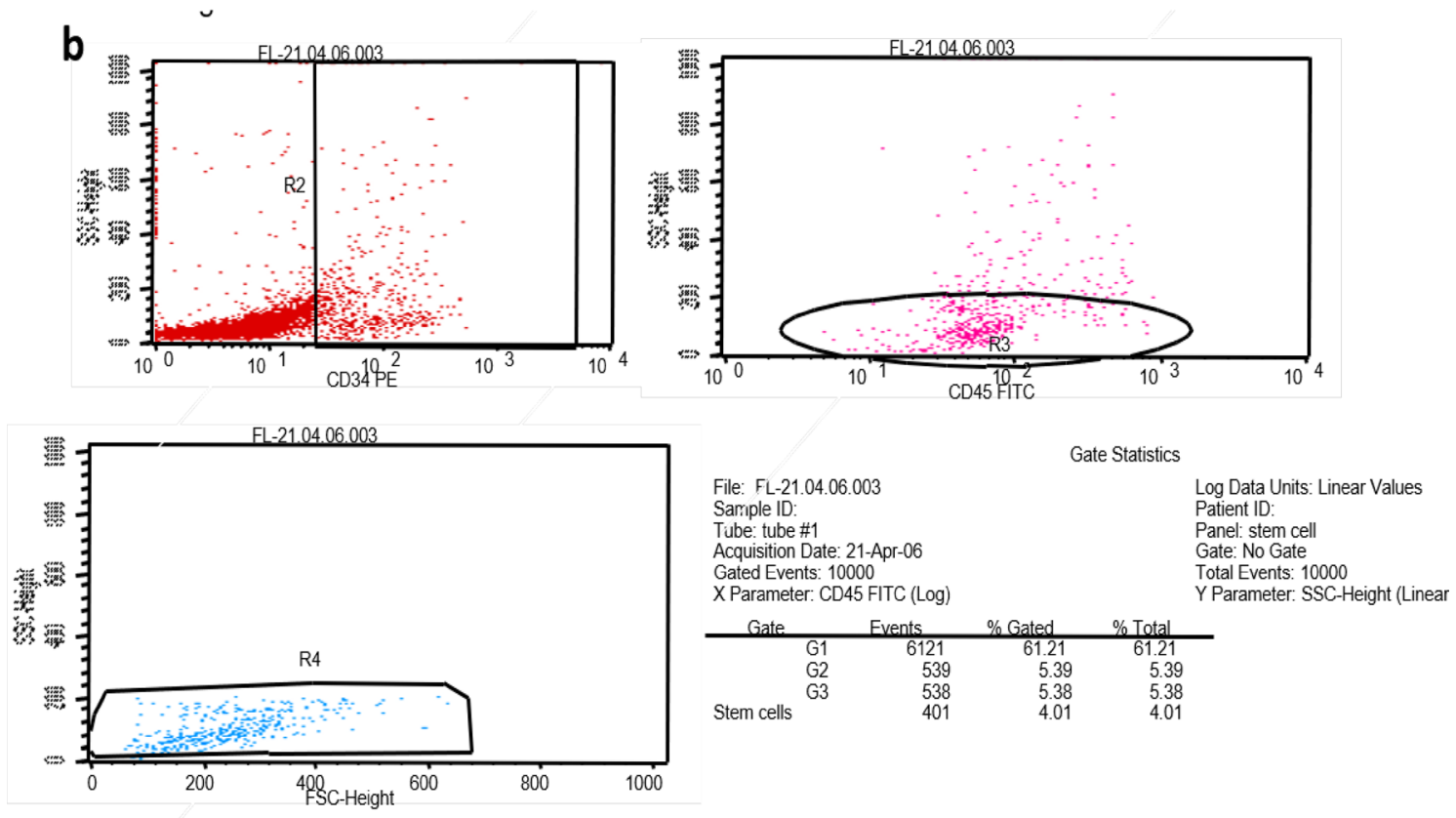

Figure 1. (a) Percentage of $\mathrm{CD} 34^{+}$cells vs. Gestation age of the fetus. CD34 ${ }^{+}$population among fetal liver mononuclear cells ranged from $1.2 \%-12.8 \%$ in $8-16$ weeks $(n=3$ for each week) gestational age of fetuses $(\mathbf{a})$ Statistical significance was analyzed via ANOVA and is depicted with asterisks $\left({ }^{*}\right)$. double $\left({ }^{*}\right)$ asterisks indicates $P \leq 0.01$. Representative primary immunophenotypic data of CD34 + cells (also tested and positive for CD45) from fetal liver mononuclear cells showing 5.39\% of total evaluated cells expressing CD34 antigen (b).

twenty-one days of culture. FACS analysis of CD34 expression of five representative experiments at different time points is shown in Fig. 3a. The Percentage of $\mathrm{CD}_{3} 4^{+}$among the total nucleated cell count at day 21 was $15.42 \pm 4.9$ in combination $\mathrm{M}+\mathrm{S}+\mathrm{M} 1,14.68 \pm 5.1 \%$ in $\mathrm{M}+\mathrm{S}+\mathrm{M} 2,18.24 \pm 4.2 \%$ in $\mathrm{M}+\mathrm{S}+\mathrm{M} 3$, and $13.08 \pm 2.3 \%$ in $\mathrm{M}+\mathrm{S}+\mathrm{M} 4$, however, in media $(\mathrm{M})$ alone it was $1.7 \pm 2.0 \%$. ANOVA analysis was adapted to assess the significance levels of difference in decline of CD34 expression between different culture conditions. The decline in CD34 + HSPCs percentage was found to be highly significant among different combination groups with $p$-value $(0.000)<0.01$ with $95 \%$ confidence level of interval. Absolute number of total cells and CD34\% cells at day 21 are given in Supplementary Table 2.

Colony forming unit assay from in vitro expanded FL-HSPCs. In vitro expanded cells FL-HSPCs were counted and analyzed every 7 days for their colony formation (CFU-GM, BFU-E and CFU-GEMM) potential (Fig. $4 \mathrm{a}, \mathrm{b}$ and c). The Colony forming potential of freshly isolated CD34 ${ }^{+}$HSPCs was $120 \pm 17$ for CFU-GM, BFU-E $161 \pm 15$ and $101 \pm 17$ for CFU-Mix. Figure 5 shows the comparison in different types of colonies gener- 


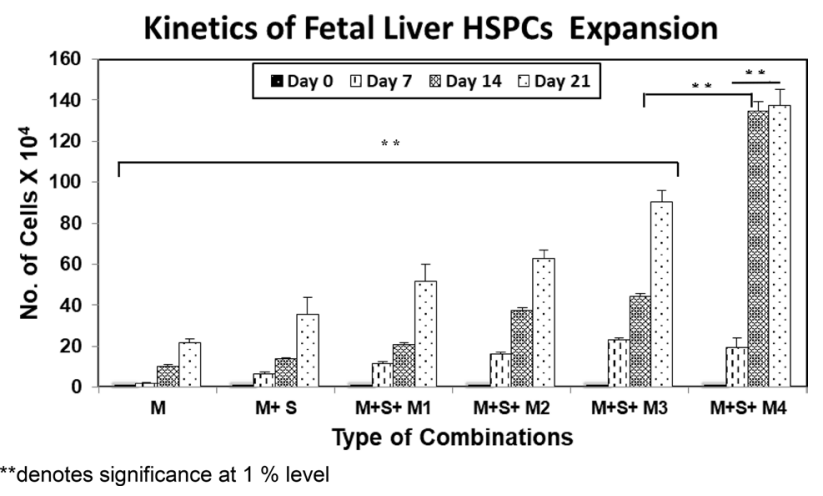

Figure 2. Kinetics of fetal liver CD34 + HSPCs expansion Estimated cell counts at 7-days intervals from day 0-24. Expansion of total cells expressed as fold increase over initial cell input in all the tested combinations. Results are expressed as mean \pm SEM of 5 experiments. Statistical significance was analyzed via ANOVA and is depicted with asterisks $\left({ }^{*}\right)$. double $\left({ }^{* *}\right)$ asterisks indicate $P \leq 0.01$. The increase in number of cells in different combinations ( $\mathrm{M}$ vs $\mathrm{M}+\mathrm{S}+\mathrm{M} 3$ and $\mathrm{M} 3$ vs $\mathrm{M} 4$ ) as well as at different days (day 7 vs Da 21 ) in $\mathrm{M}+\mathrm{S}=\mathrm{M} 4$ shows significant increase with $P \leq 0.01$.

ated from freshly isolated fetal liver CD34 ${ }^{+}$HSPCs (Day 0) with colonies generated from in vitro expanded cells collected at Day 7, 14 and Day 21 from media combination $M+S+M 4$. Decline in colony forming potential was found to be significant (p-value $(0.000)<0.01$ ) among different combination of media as well as day 14 and 21 . Morphology of different colonies produced by expanded cells at Day 21 is shown in Fig. $4 \mathrm{f}$.

\section{Discussion}

HSPCs transplantation therapy has been effectively utilized for the treatment of several life-threatening hematopoietic diseases. Bone marrow (BM) and mobilized peripheral blood are the major sources of HSPCs; however, there is a paucity of human leucocyte antigen (HLA) matched donors. Hence, umbilical cord blood (UCB) has been used as an alternative to obtain HSPCs for transplantation therapy. UCB transplantation therapy has the limitation of availability of low numbers of HSPCs per unit of UCB. HSPCs from Fetal liver can be considered as potential candidates owing to their superiority in self renewal and differentiation potential. However, sample availability, as well as consistency of fetuses in terms of fetus age and HSPC count becomes a hurdle in using this important source. In vitro expansion of HSPCs from fetal liver has the potential to provide large number of cells useful for stem cell transplants as well as experimental studies. Possibility of in vitro expansion of HSPCs has been studied by several researchers to address this issue. Combination of various growth factors have commonly been employed to expand HSPCs in vitro. Mixture of stem cell factor (SCF), thrombopoietin (TPO), and FMS like tyrosine kinase 3 ligand (FLT-3L) was found to support the expansion of HSPCs. This study verified the effect of cytokines IL-6, FLT-3L, along with the role of serum supplementation in a short-term liquid culture ${ }^{13}$. Human recombinant FLT-3 ligand $(50 \mathrm{ng} / \mathrm{ml})$ in a stroma free long term cultures has been shown to be an early acting cytokine supporting the growth of very primitive HSPCs only when synergized with other growth factors ${ }^{14}$, including SCF $(100 \mathrm{ng} / \mathrm{ml})^{15}$, IL-3 $(10 \mathrm{ng} / \mathrm{ml})^{16}$, IL-6 $(10 \mathrm{ng} / \mathrm{ml})^{17,18}$, granulocyte colony stimulating factor $(13 \mathrm{ng} / \mathrm{ml})$ and $0.4 \mathrm{U} \mathrm{EPO}^{19}$ and $10 \mathrm{U} / \mathrm{ml} \mathrm{TPO}^{14,20,21}$. With these different combinations, expansion of CD34 ${ }^{+}$ cells could be observed by day 7; expansion ranged from 2.44 to as high as $25.11 \pm 13.50$-fold by day $7^{13,14,22,23}$. Long term expansion of human fetal liver primitive hematopoietic progenitor cells in stroma free cultures was successfully achieved using media RPMI 1640 supplemented with $8 \%$ human AB plasma and a cocktail of different cytokines including FLT-3 ligand $(50 \mathrm{ng} / \mathrm{mL})$, interleukin $6(10 \mathrm{ng} / \mathrm{mL})$, megakaryocyte growth and development factor (MGDF; $10 \mathrm{ng} / \mathrm{mL}$ ), and stem cell factor (SCF; $50 \mathrm{ng} / \mathrm{mL})^{24}$. Combination of 5 cytokines namely SCF(100 ng/ml), FLT-3(100 ng/ml), IL-6(20 ng/ml), EPO (2U/ml) and GM-CSF $(200 \mathrm{U} / \mathrm{ml})$ in a serum deprived culture medium STEM PRO-34-SFM supplemented with insulin, transferrin, low density lipoprotein, glutamine and mercaptoethanol has been used by us in the current study for a period of 21 days. Expansion of nucleated cells happened by $137.24 \pm 8.1$ fold $(p<0.05)$, levels of CD34 ${ }^{+}$antigen expression however, declined steadily over this period. It has been the general observation that even when there was clear demonstration of in vitro amplification of HSPCs, there was a net decline over input numbers ( 6.5 fold after 4 weeks) indicating that the culture conditions were suboptimal for stimulating HSPCs self-renewal and/or their continued survival (25). One possibility is that growth factors might positively alter self-renewal versus differentiation decisions of stem cells (25). Expansion of nucleated cells by $137.24 \pm 8.1$ fold in the present study but the loss of CD $34^{+}$cells by day 21 is certainly consistent with this possibility. Growth factor dosing is another important issue ${ }^{25}$. At high levels of human IL-3 $(20 \mathrm{ng} / \mathrm{ml})$, GM-CSF $(20 \mathrm{ng} / \mathrm{ml})$, and SF $(50 \mathrm{ng} / \mathrm{ml})$, marked impairment of regeneration of human competitive repopulating cell (CRU) in NOD/SCID transgenic mice was noted by Nicolini et al. ${ }^{26}$. Concentrations and combination of different cytokines has proven their role in stem cell expansion studies. In one of the similar studies, although stimulation of HSPCs expansion by IL-11 was observed at low concentration range; yet saturation effects were not achieved even at high concentration with factors such as steel factor (SF) or FLT-3 ligand (FL), (>300 ng/ml) ${ }^{25}$. According to McNiece et al., SCF synergizes with other cytokines e.g., Epo, IL- 3, GM-CSF, and G-CSF to support growth of BFU-E, CFU-GM, and CFU-GEMM cells. SCF alone resulted 


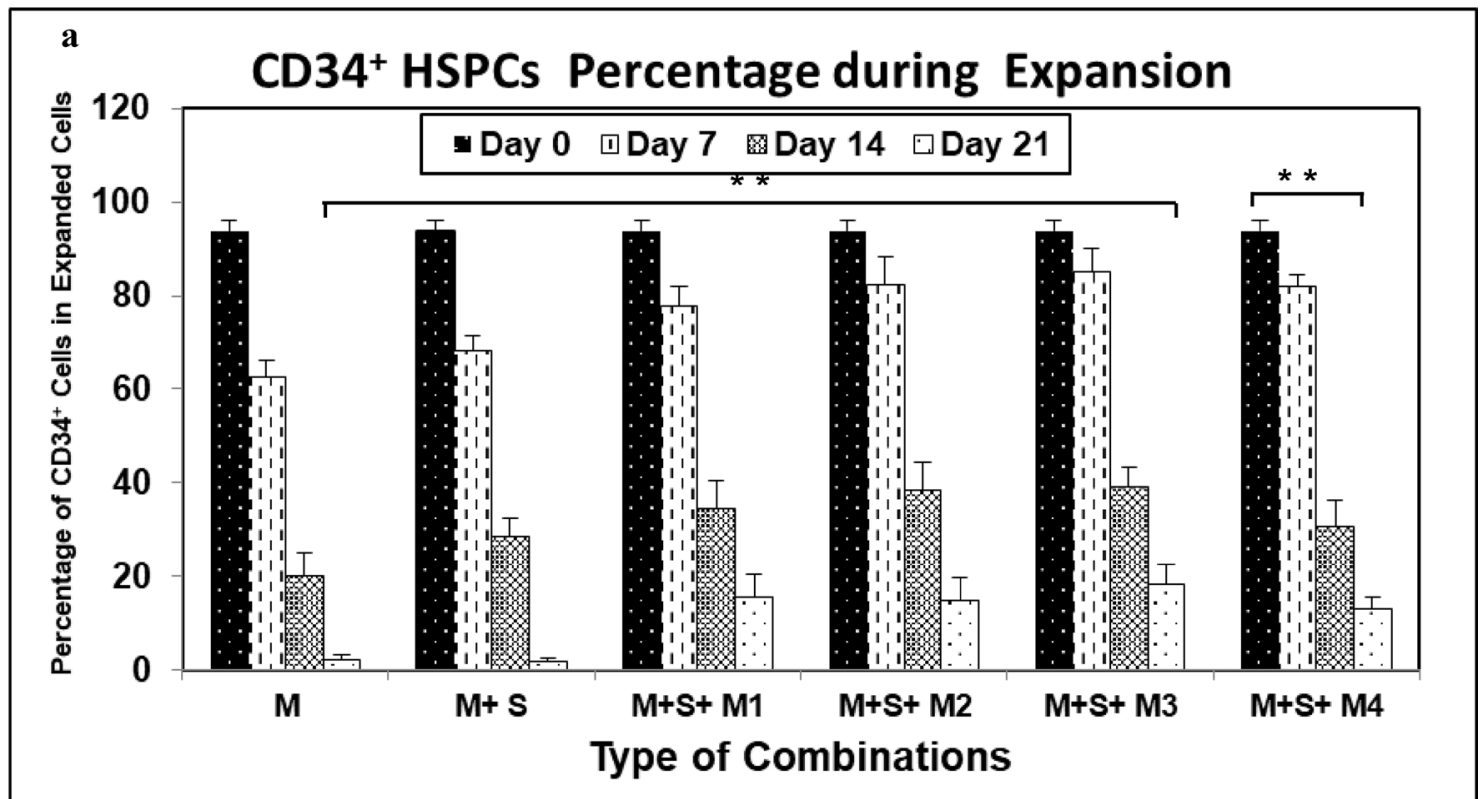

${ }^{* *}$ denotes significance at $1 \%$ level

b

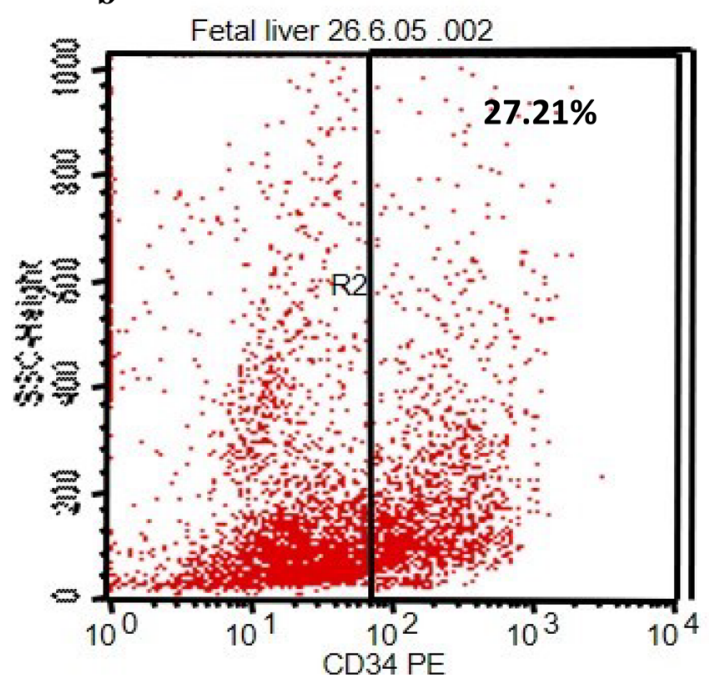

$3 \mathbf{c}$

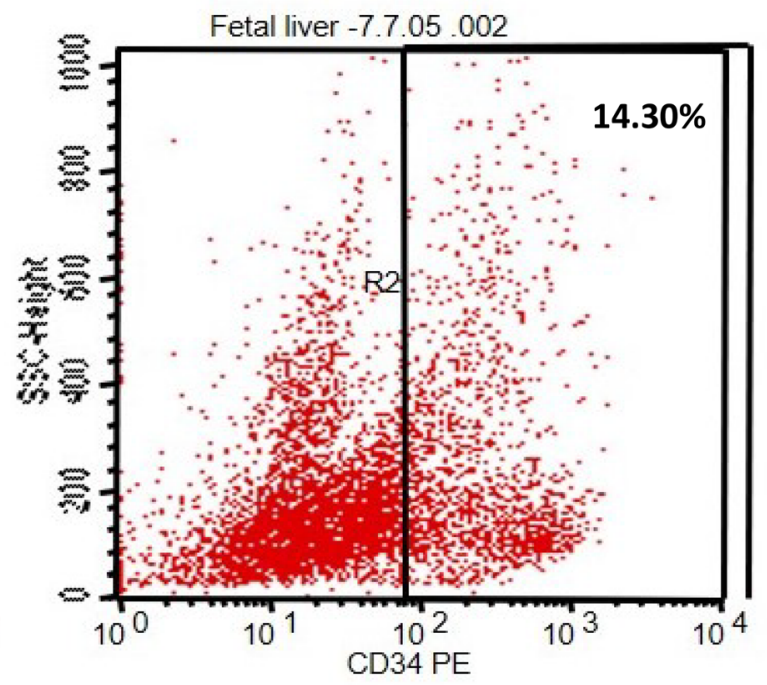

Figure 3. Percentage fetal liver CD $34^{+}$HSPCs cells during 21 days of expansion: CD34 expression of in vitro expanded cells from day 0-21 done through flowcytometry. Mean cell percentage is indicated $(\mathrm{n}=5)$ with SEM (a). Statistical significance among different combinations as well as days was analyzed via ANOVA and is depicted with asterisks $\left({ }^{*}\right)$. double $\left({ }^{* *}\right)$ asterisks indicate $P \leq 0.01$. (b) Representative image of immunophenotyping of CD34 antigen from in vitro expanded cells using $\mathrm{M}+\mathrm{S}+\mathrm{M} 4$ media and cytokines combination at Day 14 (b) and Day 21(c) done through flowcytometry.

in no significant colony formation, however, along with other cytokines viz. G-CSF and rhIL-3, SCF stimulated a synergistic increase in colony numbers ${ }^{27}$. A study by Sui et al., reported that although SCF (100 ng/ml) alone has modest effect on colony growth, but in the presence of other cytokines like of $1 \mathrm{~L}-3(200 \mathrm{U} / \mathrm{ml})$, and EPO (2 $\mathrm{U} / \mathrm{ml})$, SCF increases both the size and the number of colonies ${ }^{28}$. Our study, similar to that of Matsunaga et al., depicts that the combination of SCF $(100 \mathrm{ng} / \mathrm{ml}))$, IL-6 $(100 \mathrm{ng} / \mathrm{ml})$, and FLT-3 ligand $(100 \mathrm{ng} / \mathrm{ml})$ can support the proliferation, differentiation, and terminal maturation of BFU-E 'in vitro', even in the absence of EPO ${ }^{29}$. Transforming growth factor beta 1 (TGF beta 1 ) at concentration of $1-50 \mathrm{pg} / \mathrm{ml}$ stimulated colony formation but at higher concentration, it had an inhibitory effect ${ }^{30}$. Stimulation of selective growth factor pathways, may yet be a crucial determinant of HSPCs self-renewal. For instance, regeneration of normal HSPCs in recipients lacking TPO got impaired by 10-20-fold ${ }^{31}$. TPO has been implicated as a positive regulator of HOXb4 (part of a family of transcription factors) expression, a potent enhancer of HSPCs expansion. HOXb4 induced self -renewal in vitro even in conditions that were sub optimal for untransduced $\mathrm{HSPCs}^{25}$. Over expression of another gene namely SALL4 has also been shown to have the capacity to substantially increase the number of HSPCs in vitro ${ }^{32}$. More recently, Jing et al. ${ }^{33}$ demonstrated the expansion of both murine BM HSPCs and human UCB HSCs with the 


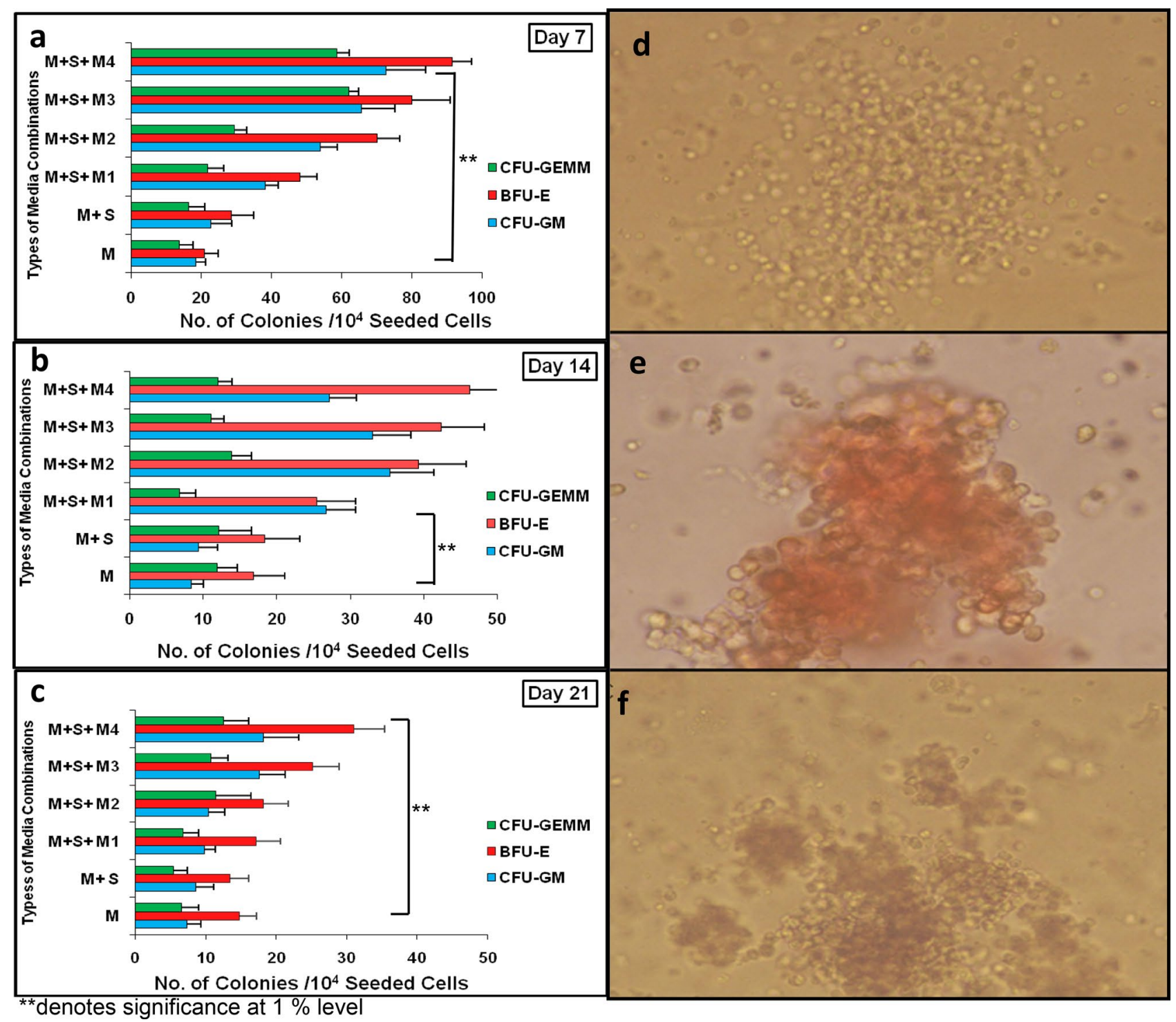

Figure 4. Colony Forming Unit Assay from invitro expanded FL CD34 + HSPCs . Number of committed progenitors (including CFU-GM, BFU-E, and CFU-Mix) derived from $1 \times 10^{4}$ Fetal liver CD34 ${ }^{+}$HSPCs after 7 days (a), 14 days $(\mathbf{b})$ and 21 days (c) of serum-free liquid suspension culture in the presence of different combinations of cytokines.M1, M2, M3 and M4 $(n=3)$. Statistical significance among colony forming potential from different media combinations as well as days was analyzed via ANOVA and is depicted with asterisks $\left(^{*}\right)$. double ${ }^{* *}$ ) asterisks indicate $P \leq 0.01$. Representative Picture of CFU-GM (d), BFU-E (e) and CFU-Mix (f) colonies derived from Fetal liver CD $34^{+}$HSPCs $(10 \times)$ from combination M+S + M4, day 14 of expansion.

combination of a moderate concentration of p38 inhibitor plus a GSK 3 inhibitor. Thus, it appears that despite the availability of various methods to expand HSPCs in vitro ${ }^{25,32}$, an ideal method to increase the number of HSPCs in vitro is yet to be discovered.

\section{Conclusion}

Fetal liver, a major site of hematopoiesis during second trimester of pregnancy is an excellent source of hematopoietic stem cells. The higher cell number required for experimental studies is hindered by poor availability of fetuses and a smaller number of cells obtained per fetus. To overcome this problem, magnetically sorted CD $34^{+}$ hematopoietic stem and progenitors cell populations have been subjected to expansion, using media supplements and different combinations of cytokines. Although the total number of nucleated cells increased in culture, levels of CD34 antigen expression declined steadily with time. 


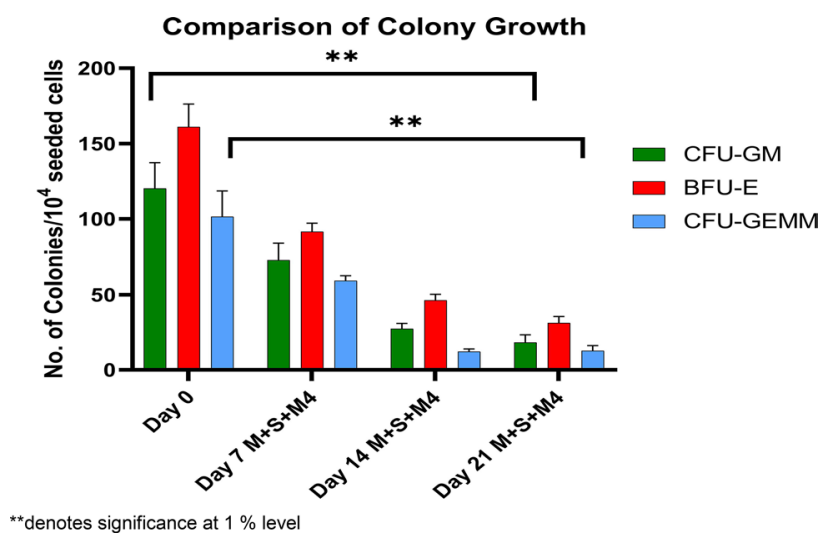

Figure 5. Colony Forming Unit Assay from $M+S+M 4$ vs Day 0 . Number of committed progenitors (including CFU-GM, BFU-E, and CFU-Mix) derived from $1 \times 10^{4}$ freshly isolated Fetal liver CD34 $4^{+} \mathrm{HSPCs}$, denoted as Day 0 vs. colonies generated from invitro expanded cells collected at day 7, day 14 and Day 21 from media combination $\mathrm{M}+\mathrm{S}+\mathrm{M} 4(\mathrm{n}=10)$. Statistical significance among colony forming potential from different media combinations as well as days was analyzed via ANOVA and is depicted with asterisks $\left(^{*}\right)$. double $\left({ }^{* *}\right)$ asterisks indicate $P \leq 0.01$.

\section{Data availability}

All data generated or analyzed during this study are included in this "to be published" article.

Received: 27 January 2021; Accepted: 15 April 2021

Published online: 04 June 2021

\section{References}

1. Barcena, A., Muench, M. O., Kapidzic, M. \& Fisher, S. J. A new role for the human placenta as a hematopoietic site throughout gestation. Reprod. Sci. 16(2), 178-187 (2009).

2. Böiers, C., Carrelha, J. \& Lutteropp, M. Lymphomyeloid contribution of an immune-restricted progenitor emerging prior to definitive hematopoietic stem cells. Cell Stem Cell 13(5), 535-548 (2013).

3. Lacaud, A. \& Kouskoff, V. Hemangioblast, hemogenic endothelium, and primitive versus definitive hematopoiesis. Exp. Hematol. 49, 19-24 (2017).

4. Bhattacharya, N. \& Pal, S. Use of human fetal tissue in bionic and biomaterial devices. Trends. Biomater. Artif. Organs. 18, 93-100 (2005).

5. Kuchma, M. D. et al. Comparative analysis of the hematopoietic progenitor cells from placenta, cord blood, and fetal liver, based on their immunophenotype. BioMed. Res. Inter. 2015, 1-16 (2015).

6. Raju, G. M. K. et al. Colony stimulating activity secreted by human fetal liver cells in comparison to normal adult bone marrow: Role in engraftment after transplantation. Blood 88(1), 258 (1996).

7. Rebel, V. I., Miller, C. L., Eaves, C. J. \& Lansdorp, P. M. The repopulation potential of fetal liver hematopoietic stem cells in mice exceeds that of their liver adult bone marrow counterparts. Blood 87, 3500-3507 (1996).

8. Moore, A. K., Ema, H. \& Lemischka, R. I. 'In vitro' maintenance of highly purified, transplantable hematopoietic stem cells. Blood 89, 4337-4340 (1997).

9. Holyoake, T. L., Nicolini, F. E. \& Eaves, C. J. Functional differences between transplantable human hematopoietic stem cells from fetal liver, cord blood, and adult marrow. Exp. Hematol. 27, 1418-1427 (1999).

10. Mehra, N. K., Taneja, V., Sharma, S. \& Kochupillai, V. HLA status following fetal liver transplantation in aplastic anemia and acute myeloid leukemia. Thymus 10, 131-136 (1987).

11. Kochupillai, V. et al. Fetal liver infusion in aplastic anemia. Thymus 10(1-2), 95-102 (1987).

12. Arjmand, B. et al. Co-transplantation of human fetal mesenchymal and hematopoietic stem cells in Type 1 diabetic mice model. Front. Endocrinol. 10, 761 (2019).

13. Mohamed, A. A. et al. Ex vivo expansion of stem cells: defining optimum conditions using various cytokines. Lab. Hematol. 12, 86-93 (2006).

14. Piacibello, W. et al. Extensive amplification and self- renewal of human primitive hematopoietic stem cells from cord blood. Blood 89, 2644-2653 (1997).

15. Defelice, L. et al. Flt3L induces the ex-vivo amplification of umbilical cord blood committed progenitors and early stem cells in short-term cultures. Br. J. Haematol. 106, 133-141 (1999).

16. Su, R. J. et al. Platelet-derived growth factor promotes ex vivo expansion of $\mathrm{CD} 34^{+}$cells from human cord blood and enhances long-term culture- initiating cells, non-obese diabetic/severe combined immunodeficient repopulating cells and formation of adherent cells. Br. J. Haematol. 117, 735-746 (2002).

17. Rappold, I. et al. Gp130-signaling synergizes with FL and TPO for the long-term expansion of cord blood progenitors. Leukemia 13(12), 2036-2048 (1999).

18. Lazzari, L. et al. Long-term expansion and maintenance of cord blood haematopoietic stem cells using thrombopoietin, Flt3-ligand, interleukin (IL)-6 and IL-11 in a serum-free and stroma-free culture system. Br. J. Haematol. 112, 397-404 (2001).

19. Fietz, T. et al. Culturing human umbilical cord blood: a comparison of mononuclear vs CD $34^{+}$selected cells. Bone. Marrow. Transplanta. 11, 1109-1115 (1999).

20. Kaushansky, K. et al. Thrombopoietin expands erythroid progenitors, increases red cell production, and enhances erythroid recovery after myelosuppressive therapy. J. Clin. Invest. 3, 1683-1687 (1995).

21. Kawada, H. et al. Rapid ex vivo expansion of human umbilical cord hematopoietic progenitors using a novel culture system. Exp. Hematol. 27, 904-915 (1999). 
22. Yao, C. L. et al. Characterization of serum-free ex vivo-expanded hematopoietic stem cells derived from human umbilical cord blood CD133 (+) cells. Stem. Cells. Dev. 15, 70-78 (2006).

23. Chivu, M. et al. The comparison of different protocols for expansion of umbilical-cord blood hematopoietic stem cells. J. Cell. Mol. Med. 8, 223-231 (2004).

24. Rollini, P. Long term ex vivo expansion of transplantable human fetal liver hematopoietic stem cells. Blood 103, 1166-1170 (2004).

25. Sauvageau, G., Iscove, N. N. \& Humphries, R. K. In vitro and in vivo expansion of hematopoietic stem cells. Oncogene 23, 7223-7232 (2004).

26. Nicolini, F. E., Cashman, J. D., Hogge, D. E., Humphries, R. K. \& Eaves, C. J. NOD/SCID mice engineered to express human IL-3, GM-CSF and Steel factor constitutively mobilize engrafted human progenitors and compromise human stem cell regeneration. Leukemia 18, 341-347 (2004).

27. Mc Niece, I. K., Langley, K. E. \& Zsebo, K. M. Recombinant human stem cell factor synergizes with GM-CSF, G-CSF, IL-3 and Epo to stimulate human progenitor cells of the myeloid and erythroid lineages. Exp Hematol. 19, 226-238 (1991).

28. Sui, X. et al. Erythropoietin-independent erythrocyte production: Signals through gp130 and $c$-kit dramatically promote erythropoiesis from human CD34+ cells. J Exp Med. 183, 837 (1996).

29. Matsunaga, T., Kato, T., Miyazaki, H. \& Ogawa, M. Thrombopoietin promotes the survival of murine hematopoietic long-term reconstituting cells: comparison with the effects of FLT3/FLK-2 ligand and interleukin-6. Blood 92, 452-461 (1998).

30. Kale, V. P. \& Limye, L. S. Stimulation of adult human bone marrow by factors secreted by fetal liver hematopoietic cells: 'in vitro' evaluation using semisolid clonal assay system. Stem. Cells. 17, 107-116 (1999).

31. Fox, N., Priestley, G., Papayannopoulou, T. \& Kaushansky, K. Thrombopoietin expands hematopoietic stem cells after transplantation. J. Clin. Invest. 110, 389-394 (2002).

32. Schuster, J. A. et al. Expansion of hematopoietic stem cells for transplantation: current perspectives. Exp. Hematol. Oncol. 1, 12 (2012).

33. Jing, L. et al. In Vitro expansion of hematopoietic stem cells by inhibition of both GSK3 and p38 signaling. Stem. Cells. Develop. 28(22), 1-12 (2019).

\section{Acknowledgements}

We gratefully acknowledge the research grant provided by the Department of Biotechnology, Government of India and AIIMS, New Delhi.

\section{Author contributions}

Dr.V.K. and Dr.L.K. designed the study. Dr.R.B. collected, assembled, analysed and interpretated the data. Dr.D.C. drafted the manuscript which was discussed amongst Dr.N. K.M., Dr. A.S., Dr. S.M. Dr.L.K. and Dr.V.K. gave the final approval.

\section{Competing interests}

The authors declare no competing interests.

\section{Additional information}

Supplementary Information The online version contains supplementary material available at https://doi.org/ 10.1038/s41598-021-91272-6.

Correspondence and requests for materials should be addressed to D.C.

Reprints and permissions information is available at www.nature.com/reprints.

Publisher's note Springer Nature remains neutral with regard to jurisdictional claims in published maps and institutional affiliations.

(c) (i) Open Access This article is licensed under a Creative Commons Attribution 4.0 International License, which permits use, sharing, adaptation, distribution and reproduction in any medium or format, as long as you give appropriate credit to the original author(s) and the source, provide a link to the Creative Commons licence, and indicate if changes were made. The images or other third party material in this article are included in the article's Creative Commons licence, unless indicated otherwise in a credit line to the material. If material is not included in the article's Creative Commons licence and your intended use is not permitted by statutory regulation or exceeds the permitted use, you will need to obtain permission directly from the copyright holder. To view a copy of this licence, visit http://creativecommons.org/licenses/by/4.0/.

(C) The Author(s) 2021 